\title{
ANALISIS PENERAPAN E-NOFA (ELEKTRONIK NOMOR FAKTUR) PAJAK SEBAGAI UPAYA UNTUK MENCEGAH TERJADINYA FAKTUR PAJAK FIKTIF DAN FAKTUR PAJAK NOMOR BERGANDA (STUDI PADA KANTOR PELAYANAN PAJAK PRATAMA MANADO)
}

\author{
Muhamad N Alhabsyi ${ }^{1}$, David P E Saerang ${ }^{2}$, Novi S Budiarso ${ }^{3}$ \\ ${ }^{1,2,3}$ Fakultas Ekonomi dan Bisnis, Jurusan Akuntansi, Universitas Sam Ratulangi, Jl. Kampus Bahu, Manado, \\ 95115, Indonesia \\ E-mail : alhabsyinovrizal@yahoo.com
}

\begin{abstract}
The purpose of this study was to find out (e-Nofa) taxes in the tax service office (KPP) in Manado. The type of research conducted is qualitative. Data is obtained by conducting interviews, literature studies, documentation and collecting documents related to research. The data taken are: Sources of information, language, organizational structure, head office and agencies, as well as interviews with the Pratama Manado tax office and taxable entrepreneurs (PKP) who use E-Nofa. The analytical method used is descriptive comparative. The stages carried out in this study are the data needed, after which transcripts of interviews are made. Then an interview is conducted by providing codes to assist in presenting and focusing what data is suitable for analysis. The results showed that the application of e-Nofa at KPP Pratama Manado was good, but it was not yet fully efficient because of some requirements of tax duties that caused an efficient level.
\end{abstract}

Keywords: e-Nofa, Taxable Enterpreneus

\section{PENDAHULUAN}

Dalam kehidupan manusia moderen saat ini, penggunaan teknologi dan teknologi informasi sudah menjadi keharusan untuk dilakukan oleh sebuah negara dalam praktek pemerintahan sebagai alternatif untuk mendukung berjalannya kegiatan pemerintahan yang baik. Di indonesia sendiri sudah menerapkan e-Government dalam memudahkan masyarakat dalam segala aktivitas dan untuk meningkatkan efisiensi internal dalam menyampaikan pelayanan publik dan proses pemerintahan yang demokratis.

Khususnya dalam aktivitas pajak, penggunaan teknologi dan informasi dilakukan oleh Direktorat Jendral Pajak untuk memudahkan pegawai pajak atau fiskus dalam menginput data wajib pajak dan memudahkan wajib pajak dalam melakukan penyetoran pajak, Sehingga wajib pajak tidak perlu datang lagi ke kantor pajak untuk melakukan penyetoran pajak. Dalam rangka untuk mengoptimalkankan pemasukan negara dari sektor pajak, Pemerintah mereformasi perpajakan disektor Pajak Pertambahan Nilai (PPN) dengan melakukan modernisasi sistem pengelolaan pajak yang lebih baik. Hal ini disebabkan karena PPN adalah penyokong terhadap pemasukan negara nomor dua disektor pajak setelah PPh (Badan Pusat Statistik 2015).

Pada Tahun 2013 Direktorat Jendral Pajak mengimplementasikan tahap pembenahan administrasi Pajak Pertambahan Nilai (PPN) dengan memperluas basis e-SPT, Validasi Faktur Pajak guna meminimalisir terjadinya penerbitan faktur pajak fiktif, Segmentasi Pengusaha Kena Pajak (PKP) dan Pilot Project e-Tax Invoice. Penomoran Faktur Pajak tidak lagi ditentukan oleh PKP sendiri, Melainkan ditentukan oleh sistem penomoran Direktorat Jendral Pajak. Sistem penomoran ini dilakuan dengan aplikasi e-Faktur kemudian mengajukan permohonan sertifikat elektronik sebagai tanda bahwa Pengusaha Kena Pajak (PKP) tersebut telah dikukuhkan oleh Direktorat Jendral Pajak (DJP) dan selanjutnya akan 
memperoleh nomor faktur pajak berbentuk elektronik atau e-Nofa. Melalui aplikasi e-Faktur Direktorat Jendral Pajak membenahi dari segi registrasi dan penomoran faktur pajak.

Pemerintah melakukan reformasi disektor Pajak Pertambahan Nilai melalui aplikasi e-Faktur sebagai cara untuk meminimalisir terjadinya kecurangan dalam pelaporan pajak yang dapat merugikan negara. Penomoran faktur pajak yang semula dibuat oleh Pengusaha Kena Pajak itu sendiri berdasarkan peraturan Direktorat Jendral Pajak Nomor Per 24/PJ/2012 tentang Bentuk, Ukuran, Tata Cara Pengisian Keterangan, Prosedur Pemberitahuan Dalam Rangka Pembuatan, Tata Cara Pembetulan atau Penggantian, dan Tata Cara Pembatalan Faktur Pajak diganti dengan e-Nofa (Elektronik Nomor Faktur) Pajak berdasarkan KEP-136/PJ/2014 tentang PKP yang diwajibkan membuat Faktur Pajak Elektronik.

\section{TINJAUAN PUSTAKA}

Konsep Akuntansi. Menurut GASB Concepts StatementNo. 1 istilah "Akuntansi" digunakan untuk menggambarkan proses perakitan, menganalisis, mengelompokkan dan merekam data yang relevan dengan transaksi dengan cara mempengaruhi pemerintah keuangan perakitan melibatkan berkumpul bersama pesanan pembelian, faktur, penagihan laporan, pemberitahuan, penerimaan, menerima slip, menutup dokumen, laporan bank, suratmenyurat, dan lainnya dokumen yang mendukung transaksi.

Akuntansi Pajak. Akuntansi Pajak adalah akuntansi yang memiliki hubungan dengan perhitungan perpajakan yang berdasar kepada aturan-aturan dan undang-undang perpajakan baik itu dalam pelaksanaannya beserta yang berlangsung disuatu negara (Muljono, 2009:1).

Pajak. Pajak merupakan komponen yang sangat mempengaruhi dan mempunyai peranan yang besar dalam meningkatkan perekonomian dan pembangunan disuatu negara. Pajak adalah kontribusi rakyat terhadap pemasukan negara yang berlandaskan undang-undang (bersifat memaksa) dengan tidak memperoleh manfaat secara langsung dan dapat dimanfaatkan untuk membiayai pembangunan atau keperluan negara (Mardiasmo 2011:1).

Pajak Pertambahan Nilai. Pajak Pertambahan Nilai merupakan pajak yang dikenakan atas konsumsi didalam negeri (daerah pabean) baik barang maupun jasa (Waluo:2012). Apabila dilihat dari sejarahnya, Pajak Pertambahan Nilai adalah pengganti dari pajak penjualan. Hal ini dikarenakan pajak penjualan sudah tidak lagi relevan untuk menampung kegiatan wajib pajak dan belum mencapai sasaran kebutuhan pembangunan, untuk penerimaan negara, mendorong ekspor, dan pemerataan pembebanan pajak. (Mardiasmo:2009).

Faktur Pajak. Faktur Pajak adalah bukti pungutan pajak yang dibuat oleh pengusaha kena pajak yang melakukan penyerahan barang kena pajak atau jasa kena pajak atau bukti pemungutan pajak karena impor barang kena pajak yang dilakukan Direktorat Bea dan Cukai. (Waluyo:83 2011). Pembuatan faktur pajak bersifat wajib bagi setiap pengusaha kena pajak.

Faktur Pajak Tidak sah. Faktur Pajak Tidak Sah/Fiktif merupakan salah satu bentuk penyimpangan terhadap aktivitas pelaporan pajak yang dilakukan oleh wajib pajak (Yamin dan Putranti 2009:2), hal ini didasari oleh keleluasaan yang diberikan Dirjen Pajak kepada wajib pajak dalam melakukan aktivitas pelaporan pajak. Sebelumnya terdapat wajib pajak yang menerbitkan faktur pajak namun belum dikukuhkan sebagai pengusaha kena pajak oleh dirjen pajak. Hal ini, sebagai akibat dari belum adanya aturan sebuah sistem yang dapat mendeteksi kecurangan faktur pajak yang terjadi serta pengawasan yang intensif dari pihak Dirjen Pajak.

Faktur Pajak Nomor Berganda. Faktur Pajak Nomor Berganda adalah merupakan bentuk penyelewengan dalam aktivitas pajak. (James W Pratt, 2012) dalam bukunya Individual Taxation mengatakan tujuan dari perencanaan pajak adalah meminimalisir dalam pembayaran pajak yang akan disetor. Dalam aktivitas aktivitas perencanaan pajak terdapat 
perbedaan yang penting antara Tax Avoidance dan Tax Evasion dimana keduanya membahas tentang penghindaran pajak, yang satu tidak melanggar peraturan perpajakan sedangkan yang satunya lagi melanggar ketentuan perpajakan. Penghindaran pajak dengan cara ilegal atau Tax Evasion adalah merupakan penerbitan faktu pajak keluaran dan faktur pajak masukan dengan nomor faktur yang sama dengan cara pengusaha kena pajak menjual barang kena pajak atau jasa kena pajak namun menggunakan satu nomor faktur yang sama. Tujuannya adalah agar Pengusaha Kena Pajak membayar pajak dalam jumlah yang kecil.

Modernsasi Perpajakan. Reformasi perpajakan pertama kali dilakukan pada tahun 1983 dimana saat itu terjadi perubahan sistem mendasar atas pengelolaan perpajakan indonesia dari sistem Official System ke sistem Self Assesment. Perubahan sistem ini bertujuan untuk mengurangi kontak langsung antara fiskus dengan wajib pajak yang sebelumnya dikhawatirkan dapat menimbulkan prakter-praktek ilegal untuk menghindari atau mengurangi kewajiban pajak bagi wajib pajak yang bersangkutan (Diana 7:2013).

e-Faktur dan e-Nofa. e-Faktur adalah aplikasi yang disediakan dirjen pajak untuk melaporkan aktivitas pajak disektor pajak pertambahan nilai. Pemberlakuan e-Faktur dimaksudkan untuk kemudahan, kenyamanan, dan keamanan bagi wajib pajak dalam melaksanakan aktivitas pajak khususnya dalam pembuatan faktur pajak. Pemberlakuan eFaktur dilakukan bertahap sejak 1 Juli 2014 didaerah tertentu sebagai percobaan, dan pemberlakuan e-Faktur secara nasional serentak dimulai pada tanggal 1 Juli 2016 (Sumber KPP Pratama Manado). Pengusaha Kena Pajak yang telah dikukuhkan wajib menggunakan eFaktur namun tidak menggunakannya, secara hukum dianggap tidak membuat faktur pajak sehingga akan dikenakansanksi pajak sesuai dengan ketentuan yang berlaku (www.pajak.go.id). e-Nofa pajak adalah merupakan bentuk peningkatan pelayanan Direktorat Jendral Pajak kepada masyarakat selain memudahkan wajib pajak yang akan melaporkan aktivitas pajaknya juga mempermudah pihak kantor pelayanan pajak dalam mengawasi pengendalian nomor seri faktur pajak yang dikontrol langsung oleh Direktorat Jendral Pajak dan diharapkan dengan adanya e-Faktur dan e-Nofa ini dapat meminimalisir terjadinya kecurangan dalam kegiatan pajak.

Pengendalian Internal. Pengendalian internal adalah sebuah rencana, metode, dan pengukuran yang dipilih untuk mengamankan kekayaan, memeriksa keakuratan, dan keandalan, serta pengawasan dalam suatu organisasi, meningkatkan efisiensi operasional, dan mendukung dipatuhinya kebijakan manajerial yang telah ditetapkan (Hesty, 2013:17). Kontrol internal membantu memastikan proses organisasi berfungsi dengan baik, mendapatkan informasi keuangan yang handal dan aman penerapan peraturan juga dicatat bahwa organisasi menetapkan kontrol untuk melindungi dari kecurangan dan penyalahgunaan.

\section{METODE PENELITIAN}

Jenis Penelitian. Jenis penelitian yang dilakukan adalah jenis penelitian kualitatif dengan menggunakan deskriptif komparatif dimana penelitian ini bertujuan untuk mengetahui efisiensi penerapan layanan e-Nofa pajak sebagai upaya untuk mencegah terjadinya faktur pajak fiktif dan faktur pajak nomor berganda pada KPP Pratama Manado. Tipe yang paling umum dari penelitian ini meliputi penilaian sikap dan pendapat terhadap individu, organisai, keadaan, ataupun prosedur. (Kuncoro, 2013:12).

Tempat dan Waktu Penelitian. Penelitian ini dilakukan diKantor Pelayanan Pajak Pratama Manado, JL. Gunung Klabat 17 Agustus, Manado. Dengan waktu penelitian, dimulai dari tanggal 1 November - 10 Desember 2017.

Metode Analisis. Peneliti menggunakan langka-langkah analisis yang mencakup reduksi, penyajian data,interpretasi data dan studi pustaka. Dari hasil analisis data kemudian dapat ditarik kesimpulan berdasarkan hasil penelitian yang disajikan dalam bentuk narasi. 


\section{HASIL PENELITIAN DAN PEMBAHASAN \\ 4.1 Hasil Penelitian}

Elektronik Nomor Faktur (e-Nofa) adalah nomor seri yang didapatkan dari Direktorat Jendral Pajak bagi wajib pajak untuk menerbitkan faktur pajak elektronik, jika sebelumnya pelaporan kegiatan pajak yang berhubungan dengan penerbitan faktur pajak dilakukan secara manual dengan mendatangi kantor pelayana pajak maka dengan diberlakukannya e-Nofa, penerbitan nomor seri faktur pajak sudah berbasi online melalui aplikasi e-Faktur. Dari hasil wawancara yang dilakukan dengan salah satu staf pegawai dikantor pelayanan pajak pratama manado, peneliti menemukan penerapan e-nofa memiliki keunggulan serta kelemahan. Keunggulannya antara lain yaitu lebih tertib adminitrasi dibandingkan dengan sebelum penerapan serta dapat meminimalisir terjadinya kecurangan seperti penerbitan faktur pajak fiktif dan faktur pajak nomor berganda. Sedangkan kelemahan dari penerapan e-nofa adalah yaitu koneksi internet dan koneksi antara loket KPP Pratama Manado dengan pusat yang sering bermasalah sehingga dapat mengganggu proses aktivitas kegiatan perpajakan. Penelitian ini juga melakukan wawancara dengan salah satu pegawai BUMN yang menggunakan aplikasi e-Faktur dan e-Nofa dan dari hasil wawancara peneliti menemukan beberapa keunggulan yaitu penerapan yang sudah baik secara umum untuk mencegah terjadinya kecurangan karena apabila wajib pajak melaporkan pajaknya melalui aplikasi kemudian terjadi kesalahan maka akan terbaca secara otomatis oleh aplikasi tersebut. Namun dalam pelaksanaannya aplikasi e-Faktur dan e-Nofa juga memiliki kelemahan seperti ketergantungan dengan jaringan internet sedangkan penyebaran internet masih belum merata secara nasional, hasil laporan yang berbentuk pdf yang kemudian akan disetorkan lagi di kantor pelayanan pajak pratama manado.

\subsection{Pembahasan}

Berdasarkan hasil wawancara yang dilakukan serta data-data yang dikumpulkan, maka peneliti menganalisa bahwa penerapan elektronik nomor faktur pajak di KPP Pratama Manado sudah baik secara sistem administrasi untuk melaporkan kegiatan pajak yang berhubungan dengan penerbitan faktur pajak dalam upaya mencegah terjadinya faktur pajak fiktif dan faktur pajak nomor berganda yang dapat merugikan negara. Karena keleluasaan yang diberikan sebelumnya oleh direktorat jendral pajak telah dicabut dan semua kegiatan yang berhubungan dengan penerbitan faktur pajak langsung ditentukan oleh pihak dirjen pajak. Akan tetapi dalam pelaksanaannya, peneliti menemukan ada beberapa kendala yang dapat mengurangi tingkat efisiensi seperti, jaringan antara loket di KPP Pratama Manado dan pusat yang sering bermasalah, koneksi internet yang tidak stabil dan belum merata bagi para wajib pajak, hasil laporan dalam bentuk pdf yang masih harus disetorkan lagi di KPP Pratama Manado secara manual serta masih banyak wajib pajak atau pengusaha kena pajak yang masih belum mengerti bagaimana menggunakan aplikasi e-faktur dan e-nofa tersebut. Selain itu peneliti juga menemukan bahwa banyak wajib pajak atau pengusaha kena pajak yang telah dikukuhkan oleh direktorat jendral pajak namun belum menggunakan aplikasi e-faktur yang disediakan. Dari data yang diperoleh langsung dari Kanto Pelayanan Pajak Pratama Manado sampai dengan 12 Desember 2017 jumlah wajib yang telah dikukuhkan oleh KPP Pratama Manado berjumlah 4.027 wajib pajak. Namun, yang menggunakan aplikasi e-faktur yang telah disediakan hanya berjumlah 1.812 wajib pajak yang mana belum mencapai setengah dari jumlah wajib pajak yang terdaftar. Menurut pegawai staf KPP Pratama Manado hal ini disebabkan oleh kesadaran membayar pajak yang kurang diwilayah Manado.

\section{Pengendalian intern di KPP Pratama Manado}

1. Lingkungan Pengendalian. KPP Pratama Manado merekrut karyawan yang memiliki kompetern, jujur dan memiliki keahlian. Hal ini dapat dilihat dari kebijakan manajemen, yaitu berupa langkah-langkah penerimaan calon karyawan yang ketat melalui tahapan 
yang telah berlaku. Perusahaan memiliki Standar Operating Proseduryang harus diikuti oleh setiap pegawai dan berbeda untuk masing-masing bagian.

2. Penilaian Resiko. Untuk mengantisipasi kecurangan KPP Pratama Manado telah memiliki prosedur dan aturan dalam melaksanakan setiap aktivitas pajaknya.

3. Aktivitas Pengendalian. Untuk memaksimalkan penerimaan pajak disektor Pajak Pertambahan Nilai dan meminimalisir penyelewengan pajak yang terjadi, KPP Pratama Manado melalui Direktorat Jendral Pajak memanfaatkan teknologi dan teknologi informasi untuk memudahkan wajib Pajak dalam menyetorkan dan melaporkan aktivitas pajaknya.

4. Informasi dan Komunikasi. Aktivitas kegiataan perpajak di KPP Pratama Manado sudah berjalan dengan baik dengan memanfaatkan sistem yang berbasis internet yang terkomputerisasi untuk menunjang ketivitas dan kegiatan pajaknya. Selain itu pihak KPP Pratama Manado memanfaatkan media sosial seperti Instagram, Facebook, Twitter untuk memberikan informasi dan edukasi kepada wajib pajak yang masih sulit dijangkau.

5. Pemantauan (Monitoring). Manajemen KPP Pratama Manado telah memberikan tanggung jawab kepada masing masing pada kepala bagian secara jelas dan sesuai dengan SOP yang berlaku.

\section{KESIMPULAN DAN SARAN}

\subsection{Kesimpulan}

Setelah penelitian yang telah dilakukan tentang peneraan layanan Elektronik Nomor Faktur (e-Nofa) pajak sebagai usaha untuk meminimalisir terjadinya faktur pajak fiktif dan faktur pajak nomor berganda pada Kantor Pelayanan Pajak Pratama Manado peneliti kemudian menyimpulkan bahwa secara umum sudah baik untuk meminimalisir terjadinya faktur pajak fiktif dan faktur pajak nomor berganda namun belum sepenuhnya efisien karena adanya kendala-kendala yang dapat mengurangi tingkat efisiensi.

\subsection{Saran}

Berdasarkan uraian di atas dapat dikemukakan saran yang kiranya dapat dijadikan pertimbangan, antara lain:

1. Diperlukan perbaikan dalam sistem jaringan dan pembaruan aplikasi dengan fitur-fitur terbaru yang lebih praktis sehingga dalam pelaksanaannya, dapat berjalan secara lebih baik dan efisien.

2. Dalam meningkatkan kesadaran wajib pajak pihak KPP Pratama Manado perlu lebih giat lagi melakukan pemberian informasi dan sosialisasi mengenai pajak melalui media sosial dll, sehingga akan berdampak pada peningkatan penerimaan negara dari sektor Pajak Pertambahan Nilai.

3. Perlu adanya unit yang turun langsung dilapangan untuk mendatangi wajib pajak atau pengusaha kena pajak yang terdaftar di KPP Pratama Manado.

\section{DAFTAR PUSTAKA}

Badan Pusat Statistik, 2015. (www.bps.go.id) Tentang Penerimaan Pajak.

Diana, Sari, 2013. Konsep Dasar Perpajakan 2013. Bandung : Penerbit PT Refika Aditama.

Direktorat Jendral Pajak 2014. (www.pajak.go.id) Tentang kewajiban pengusaha kena pajak menggunakan aplikasi e-Faktur dan penerbitan elektronik nomor seri faktur pajak.

Direktorat Jendral Pajak, 2012. (www.pajak.go.id) Peraturan Kementrian Keuangan 2012 Nomor Per 24/PJ/2012 Tentang Faktur Pajak.

GASB, Concept Statement No. 1 Objective Of Financial Reporting : $(62-68)$ 
Hesty H, 2013. "Penerapan Struktur Pengendalian Intern DAlam Menunjang Efektivitas Pemberian Kredit Usaha Pada PT. Bank Rakyat Indonesia (persero), Tbk KCP Boulevard Manado".

James W Pratt, 2012. Individual Taxation 2012. Maine USA : Penerbit Cengange Learning.

Kuncoro, 2013. Metode Riset untuk Bisnis dan Ekonomi, Edisi 4. Jakarta : Penerbit Erlangga.

Mardiasmo, 2009. Perpajakan Edisi Revisi 2009. Yogyakarta : Penerbit ANDI

Mardiasmo, 2011. Perpajakan Edisi Revisi 2011. Yogyakarta : Penerbit ANDI

Muljono, 2009. Tax Planing Edisi Pertama. Yogyakarta : Penerbit ANDI

Waluyo, 2011. Perpajakan Indonesia Buku 1 Edisi 10. Jakarta : Penerbit Salemba Empat

Waluyo, 2012. Akuntansi Pajak (Tax Accounting) Edisi Empat. Jakarta : Penerbit Salemba Empat

Yamin, Luiyanto, Putriani, Titi Muswati, 2009. Model Penyelewengan Pajak menggunkan Faktur Pajak Fiktif. Jurnal ilmu administrasi dan organisasi Vol 16 No 1, Hal 1-7. 